\title{
THE INFLUENCE OF ARCHITECTURAL HISTORY IN FINDING OUR EGYPTIAN IDENTITY AS A LANDMARK.
}

\author{
Nisreen Samy Abdeen \\ Lecturer in Architectural Department, Heliopolis HU University (HU)
}

\begin{abstract}
:
Egypt faces a great shortage in having a distinctive architectural identity, out of linkage absence with its inherited architectural legacy. Throughout history, Egypt is not able to maintain a clear unity of style, due to the successive overlapping of different cultures that turn to be odd .In light of the previous context, the researcher aim to answer the evolved questions: What is the suitable style to achieve a clear identity and aesthetical unity for modern Egyptian architecture?, how can we reuse our past in a compatible efficiently way without changing its identity features? How can we save our heritage from being vanished, from its systematic misuse?, Can we apply a general methodology for the entire country to cope with all various conditions?, Taking into consideration that the criteria of the selected style is driven by revitalizing and appreciating past cultural tangible and intangible heritage.
\end{abstract}

The methodology of this research is based on analyzing specific case studies in Cairo and Alexandria, which have unity in its architectural style, presenting the link between past and present by reusing these inherited buildings. Conclusion is classifying the percentage of both saved historical and new added modern features in our inherited buildings, inventing a descriptive methodology by showing the historical impact in a physical way, to preserve the past and create new architectural future visions. As Anderson says, 'what

let Egyptian cities unique by their culture, not just by their history but identified more by old suburbs, mosques, and churches'.

Keywords: Egyptian architectural identity, stylistic unity, adaptive reuse, descriptive methodology.

\section{Methodology}

The façade identity plays a great role in showing its constructive side, identifying its function correctly. This reflects by comfort and loyalty to the place, instead of vanishing of our heritage, for not knowing its value. Accordingly, the paper aims to link between present and past upon analysis, to figure out the reasons for the identity legacy that let Egypt doesn't have national identity. So the research is highlighting on the unity of Egyptian culture in finding ad -choc solution to return back its aesthetical style ,to increase the loyalty to the place , and upgrade the city for tourism .Assessing this methodology social ,economic ,cultural and climatic conditions to revitalize the past inherited value ,and mingling it to be reused in our daily life, maintain its symbolism value. 


\section{Introduction}

The Egyptian art and architecture style lasted till the native Pharaonic dynasties ending with the conquest of Alexander the Great in 332 BC. Referring to this, the art historian Ernest Dobrich underlines the importance of the great unity in architectural styles shown in its form, paintings and ornaments in a clear way, "It is one of the greatest things in Egyptian art that all the statues, paintings, and architectural forms seem to fall into place as if they obeyed one law, which the creation of all peoples seem to obey, a style"

This style turns to have a change upon the need to modernisation to cope with the contemporary needs. According to Banister Fletcher the ancient Egyptian style is preceded along uninterrupted traditions, and when necessary dictated a change in the methods of construction or the materials used.

From the first century BC Egypt has never been entirely expressive by its own culture, but turn to be dominated by different cultures. Even the dominating Islamic architecture is not exclusively Egyptian, as it incorporates various backgrounds and values from different urban context around the Middle East.

National identity and modern regionalism. Definition of National identity differs upon the region itself, such as by building diplomatic houses. As in our recent time, the architecture of the diplomatic building expresses the Egyptian's politics national identity (JashariKajtazi, 2014). The national identity should combine this identity with cultural identity, merging it in an ecological multinational component.

scientific study

defining case study

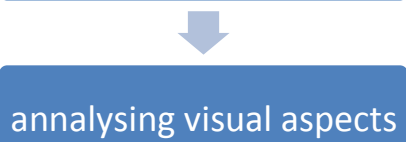

comparative analysis

before and after design

human activites, and its impact

Figure (1) shows the methodology phases for finding its architectural identity

\section{1-Assessment methodology for architectural identity:}

- Identifying the building architectural style, and its impact on the urban identity.

- Identify the openings shape, changing its architectural style through it.

- Applying unity for the façade, and changing what its odd.

- identify the type of materials that reflects on its architectural style, shape, texture, and its integration with the environment topography.

\section{1-2-Architectural style standards:}

The research approach is creating methodology for assessing the qualitative of architectural style for existing building, and analytic approach for the landmark in districts to use it as a basic design for its architectural identity process. The case studies are documented by archive analytic way, showing its details as a variable indicator. The case studies demonstrate the visual identity as a significant element for the building envelope, clarifying its material, style, function, and its social level. In each case the relationship between the visual identity of the building, and the architect influence on urban identity, linking all this to local authority to have a positive impact influenced on the design process. The research presents opportunities to create a distinctive iconic buildings brand style, creating Urban regeneration for new building. The existing building, history and its location can provide 
points of brand awareness and reputation, to distinguish between its Originality/value. The research aims to create methodology to examine architecture's role in visual identity.

Table (1) shows the constant and variable indicators for assessing architectural identity.

\begin{tabular}{|l|l|}
\hline Architectural spaces level & $\begin{array}{l}\text { Asses the Controlling factors affecting architectural } \\
\text { identity and its impact level }\end{array}$ \\
\hline $\begin{array}{l}\text { Architectural style, shows the } \\
\text { recent National style, reflecting its } \\
\text { social level. }\end{array}$ & $\begin{array}{l}\text { Architectural style, is a projection of the architect's } \\
\text { school }\end{array}$ \\
\hline $\begin{array}{l}\text { The social level reflects on the } \\
\text { Regional style, and its building } \\
\text { status circumstances }\end{array}$ & Regional Architectural identity \\
\hline $\begin{array}{l}\text { Assessing the building integration } \\
\text { with the urban context, and natural } \\
\text { environment. }\end{array}$ & Analytic survey for the existing Urban context \\
\hline
\end{tabular}

\section{1-3-Historical Analysis of Egyptian architectural identity}

The fact that architecture represents the identity of a community by its geography, traditions, behaviours, visions, and history of a community and region. As a reference to our heritage, the researchers find out through centuries that the Islamic architecture was a dominating distinguished style since the introduction of Islam in Egypt in the seventh century by having a new cult and religious practice attached to various architectural identities from early Islamic period - Umayyad, Abbasid, and Ikhshidy Dynasties (661 A.D. - 969 A.D.) till the Ottoman period (1517 A.D. - 1798 A.D.)

The breakaway from Islamic architectural style will start in Egypt by the arrival of the French campaign in the eighteenth century under the leadership of Napoleon Bonaparte. This event will mark the end of the Ottoman control over Egypt, where it reflects on the Egyptian architectural style by new compositions. From which Mohamed Ali turn to have a copy of Europe in Egypt away from its traditional architectural style, as seen in the shown example in figures $1 \& 2$, an illustration of the influence of Italian architecture in the heart of Alexandria blending Moorish arches in a perfect harmony with the gothic detailing borrowed from the Doge's palace.
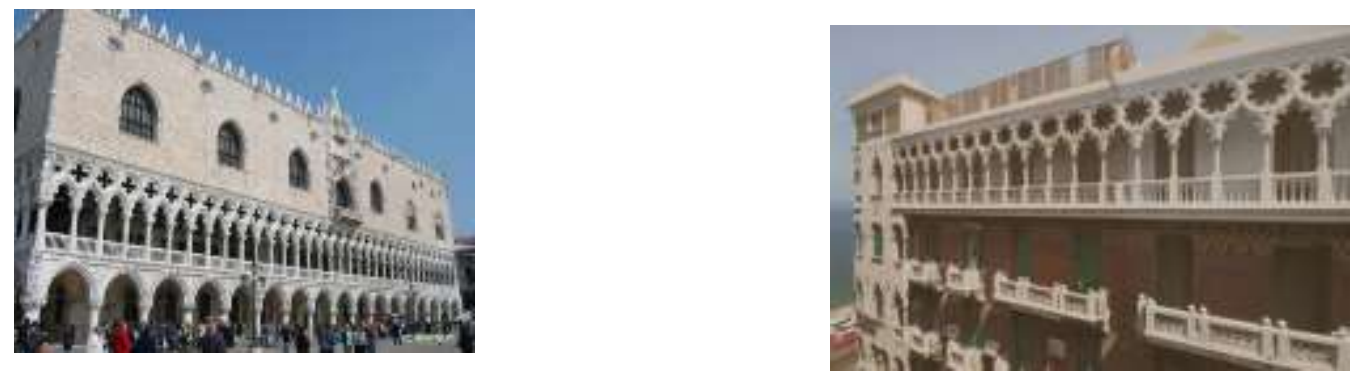

Alexandria

The transformation applied in Egypt shown by implementing new public places such as theatres, opera houses, public gardens and modern infrastructure inspired by Haussmann's renovation plan of Paris.

As seen in figures $3 \& 4$, both of Cairo and Vienna opera houses were built in 1968 had the same forms, following the dominating architectural style of its era, which proves that the identity turned to be global, not local.

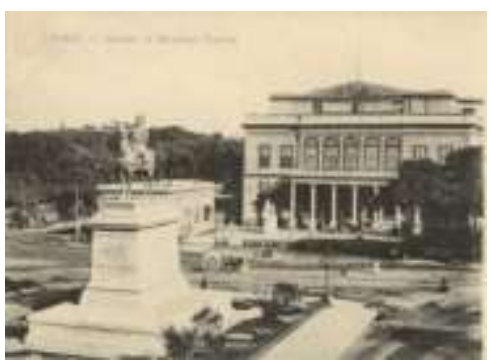

Figure( 3) the old Cairo Opera House

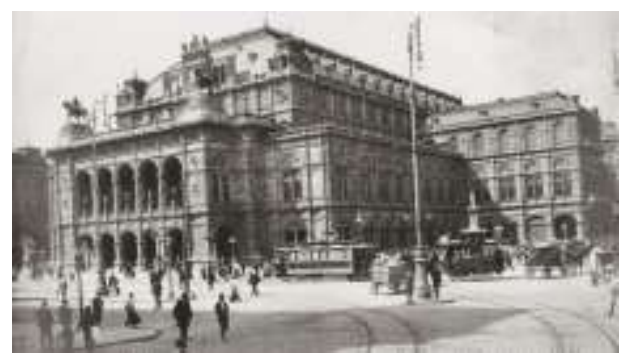

Figure( 4 )Vienna Opera House

First: Recently, a distinctive Egyptian style is not observed in modern and contemporary architecture. The research goal aim to obtain an identified architectural style based on our heritage.

The descriptive methods applied in classifying recent architectural styles in Egypt in a physical way based on Observation obtained from its long cultural civilized history. It is varied upon its different environmental regions, which is considered to be expressive of its environment and society.

Secondly: by the observation output, architectural style is classified into three main types which are Formal Traditional Architecture, Public- Middle Class Architecture, and Dominant Popular Architecture, illustrated in figure (5).

Hence, the research tries to set an emphasised methodology based on the previous Egyptian architectural legacy to reach to its national identity related to its heritage to blend past with present in terms of style.

In that way this paper verifies the importance of the descriptive methodology to highlight the priority of historical physical impact, to preserve the past, to let it a reference for our new future visions.

Neighborhoods

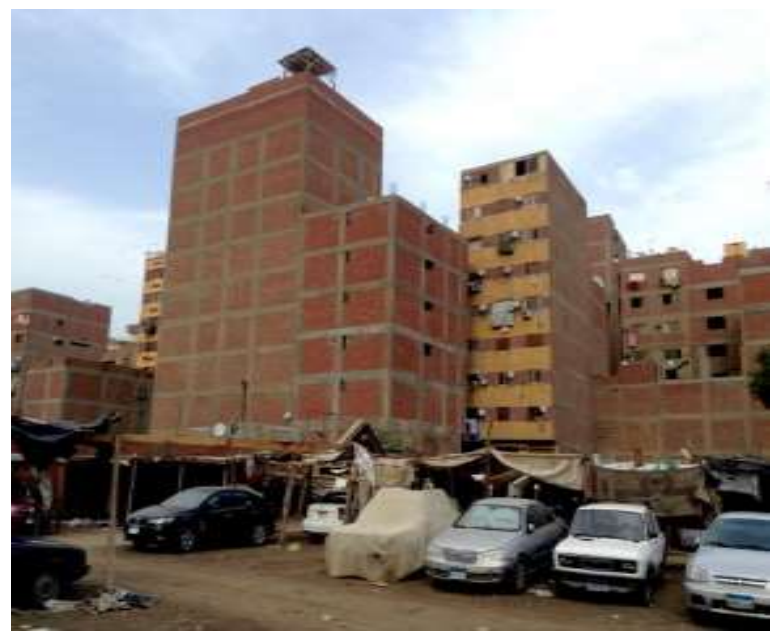

Figure ( 5 ) Cairo's Red Brick

\section{2-Confusion in Architectural identity in the time of modernization}

In The end of the $20^{\text {th }}$ century in Egypt, architects tried to find an appropriate architectural style reliving history to build a unique local identity. The researchers hypothetically assumed that there are three main cultural influences on the Egyptian architectural identity, with a strong reference to history, which are Pharaonic, Coptic, and the Islamic.

The insufficient interpretation of Egyptian architectural identity with its functional context (case studies). Consequently, the role of symbolism using the above mentioned three eras spread in 
modern architecture in a great scale, trying to save our architectural identity by implementing historical revival, historic eclecticism, and illogical approaches of collage.

This approach was glorified in many public buildings influenced by the international postmodernism movement, since the modernism was not able to satisfy emotional tie between society, the built environment and cultural needs, which would help to establish a sense of belonging.

The most significant example is The Supreme Court of Egypt located in Maadi - Cairo in 1999 By Ahmed Mito illustrating the vocabulary of ancient Egyptian architecture in a present modern style.

Where its external facades don't give the identity of its function as a court but instead it gives the impression of Egyptian antiquities museum. There no identified form for courts since the original design of tribunal chamber of the king, or

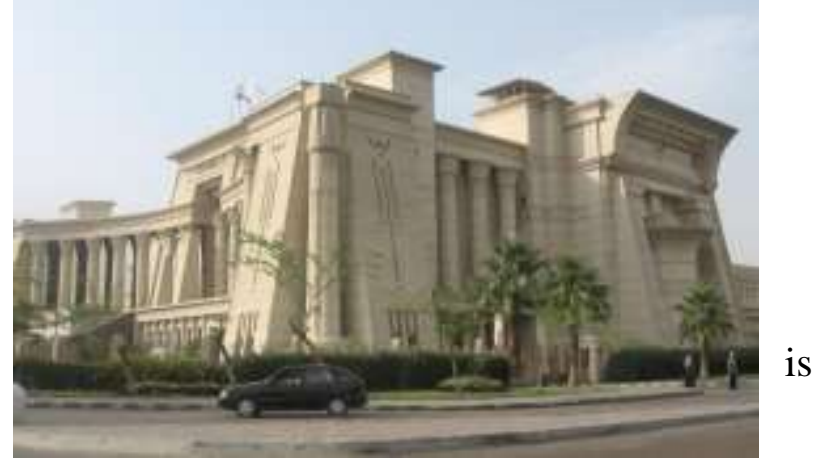

Egypt.

what is commonly known as "Basilica" or in inherited temples shapes to give the prestigious feeling. The function plays an upper role in design in satisfying its context, where the courtroom is offered as the "interface" among the differently routed individuals, and this is not accomplished in Mito's Design.

Hence there is no identity for the function, it gives confusion to the architect for having no reference guide, or freedom for innovative approach for finding a real identity that reflects its function in the form, volume and facades. This status is what the Egyptian architecture faces by now in having a shortage in identifying it as a significant architectural style.

\section{3-Interpretation of Egyptian architectural identity through landmarks}

The current study aims to find new concepts for architectural identity and its categories in general, but specific to the context of Egyptian culture. The foreign affairs ministry building in Egypt (Figure 7) is a successful example with multiple ethnic or national identities inspired by ancient pharaonic lotus flower (Figure 8), as a symbolism for its piles in concurrence with modern skyscraper, attempting to find a good representative updated image for Egypt.
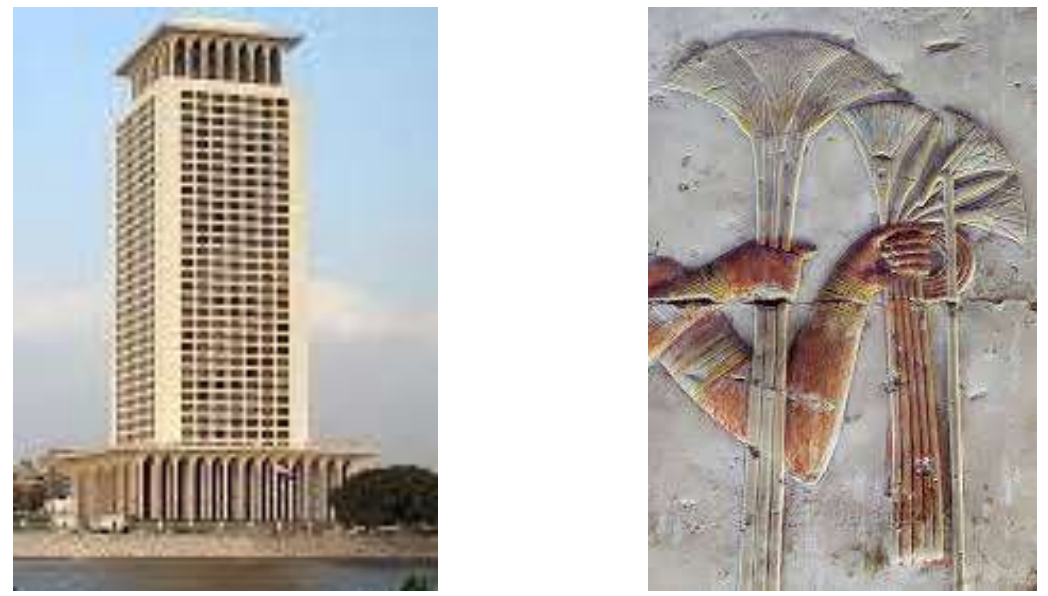

Abydos

Accordingly, the lotus flower turns to be an iconic representative symbol for Egyptian architectural identity; this is quite obvious in the entrance of Cairo International Convention \& Exhibition Center fig (10), Luxor International Airport fig (11), and Aswan High Dam Monument fig (12).
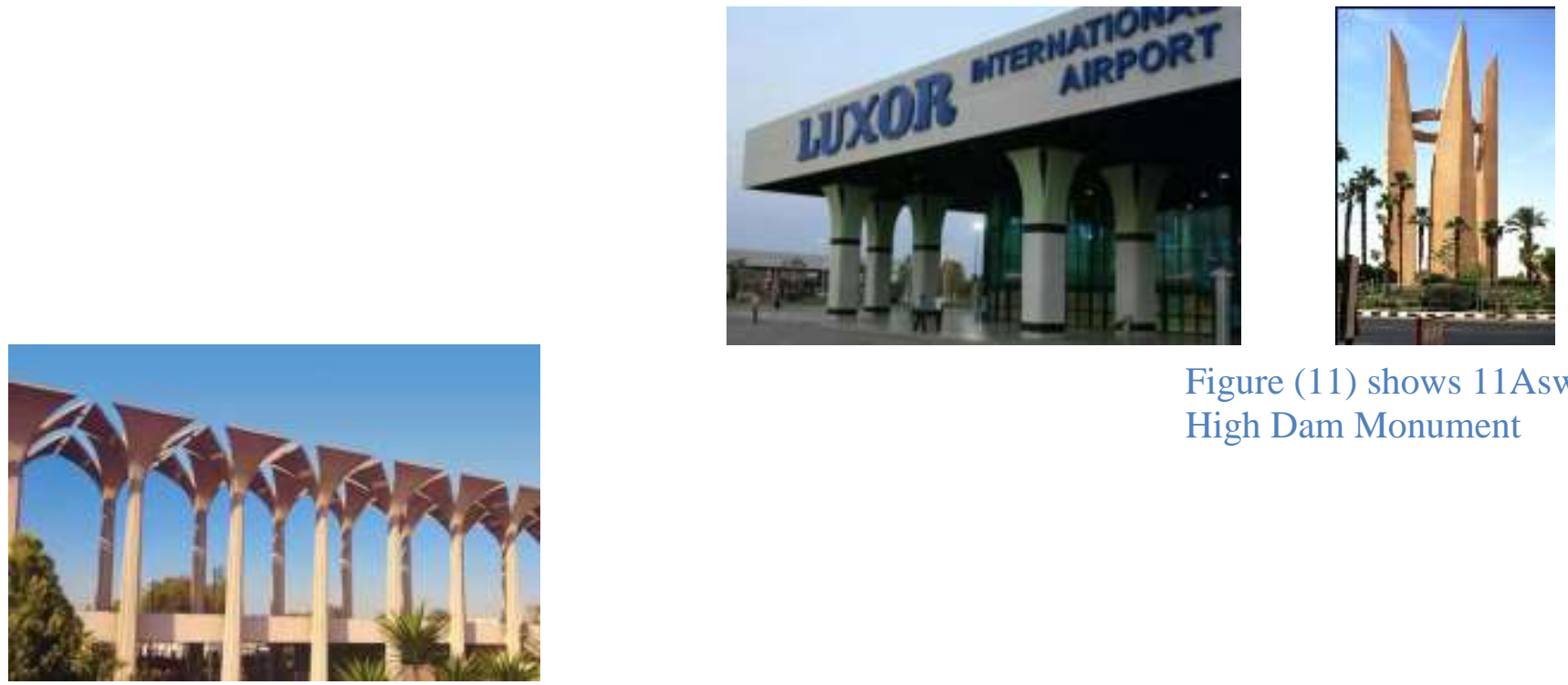

Figure (11) shows 11Aswan

High Dam Monument

Figure (9) Cairo International Convention Figure (10)Luxor International Airport

On the other hand, this approach was preceded in Europe and America in the nineteenth century as a subjective distinguished Egyptian revival movement (fig 13 The Medical College of Virginia), attributed generally to the public awareness of ancient Egyptian monuments.

Ascending to this case, followed Egyptian trials came after it by two centuries in a symbolic way.

\section{4-Suggested Rules for saving the architectural identity}

Rules should be respected before being prohibited to apply it, as our goal is to save and preserve the Egyptian cities identity through the

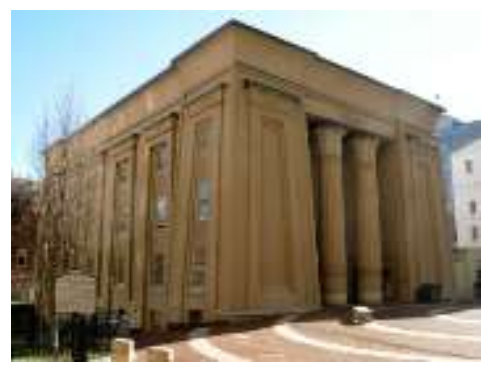
architect's identity rules as a whole set. As architecture form is a piece of art in a bigger scale, showing the sense artistic expression and tradition culture context as foundations for cites individual creativity. Where, it should not be a copy of remodeling our daily needs, but giving image the reality of memories, as it is our identity heritage. (Pallasma, 2007, p. 139).

\section{4-1-Renovation of architectural identity}

Creating a new identity starts from renovation, to emerge the past inherited identity with the present, showing its instant time interval, with the suggested ruled preserving identity rules as reinterpretation character. Architecture identity reveals the society development level, where it is the real nation reflection of style, merging its historical regions, in an efficient frame serving the society 
needs. In order to achieve the research methodology in creating ideal architectural city image as a landmark, we have to use natural resources to fulfill society goals coping with its climate, reflecting its architectural identity. It depends upon doing a whole survey as analytic way to the surrounded environment, to cope with the updated changes, to reach to the ideal specific architectural style.

First phase: applying analytic survey by assessing constant and variable factors affecting architectural identity, and quantify its value by the updated changes that affects the building style, and merge between the environment context and manmade changes, matching with its typography and circumstances, filtrating this into certain elements, that reflects on its external form and style. The paper goal is to create holistic methodology merging between human resources as a heritage and updated needs, mingling all with its urban context. So architectural details reveal the type of its style, if it is European or Arabian, showing its standard level as an obvious image in its external frame. So, building frame create loyalty, whole city image as zones, or districts, upon its specific style, it identifies its priority, defined by Kevin Lynch.

Table (2) showing the methodology for assessing Architectural identity factors

\begin{tabular}{|l|l|l|}
\hline Architectural identity factors & Constant factors & Variable factors \\
\hline Architectural form & Circulation & Aesthetical \\
& Specific Urban contents & Buildings types \\
& Walkways & Form and spaces \\
Site signals & Building Heights \\
& Squares & Compatible functions \\
& Context approaches & Architectural spaces \\
& & Land use \\
\hline
\end{tabular}




\begin{tabular}{|c|c|c|}
\hline Urban context & $\begin{array}{l}\text { Site } \\
\text { Climate } \\
\text { Borders } \\
\text { Typography } \\
\text { Contour } \\
\text { Logistics } \\
\text { Aesthetical vision } \\
\text { Natural elements }\end{array}$ & $\begin{array}{l}\text { Interaction } \\
\text { Landscape } \\
\text { Illumination } \\
\text { Views } \\
\text { Wind } \\
\text { Shade } \\
\text { Form } \\
\text { Contrast and unity } \\
\text { Architectural system } \\
\text { Mind aspects } \\
\text { Local architects } \\
\text { External elements of the } \\
\text { building }\end{array}$ \\
\hline Architectural language & $\begin{array}{l}\text { Location } \\
\text { Historical distribution } \\
\text { Sector lines } \\
\text { Materials } \\
\text { Color -touch } \\
\text { Ornaments } \\
\text { Details } \\
\text { Entrances } \\
\text { Openings } \\
\text { Close openings }\end{array}$ & $\begin{array}{l}\text { Local architectural form and } \\
\text { hierarchy } \\
\text { Building lines } \\
\text { Elevation width } \\
\text { Skyline } \\
\text { Rhythm } \\
\text { Architectural aesthetical view }\end{array}$ \\
\hline
\end{tabular}

4-2-The role of window openings, ceilings, materials in identifying the Architectural style: 
So, the research focus on creating methodology to define the factors assessing the architectural identity through constant and variables factors. Where the time, typography, geological and geographical and climate are constant factors. On the other hand, defining the variables positive, and negative impact, architectural style, as Materialistic sector, shown in its urban context environment, a social factor and updated expansion factors. So, the space affects the whole visual aspect image as connected chain of buildings, as an urban context that identifies the walkways frontage, and architectural spaces.

\section{5-The environment impact on our historical buildings Aesthetical visual:}

So, the Climatic change is an essential role in affecting the building long interval of time and its performance. Energy saving techniques plays an important role in creating the district identity, for applying good isolation.

Figure (13) showing FUE (future university)

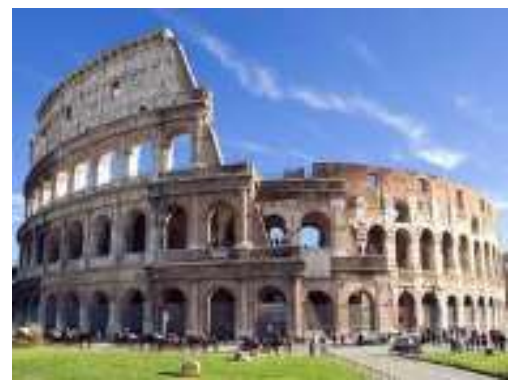

Figure (14) shows Colosseum in Rome, Italy

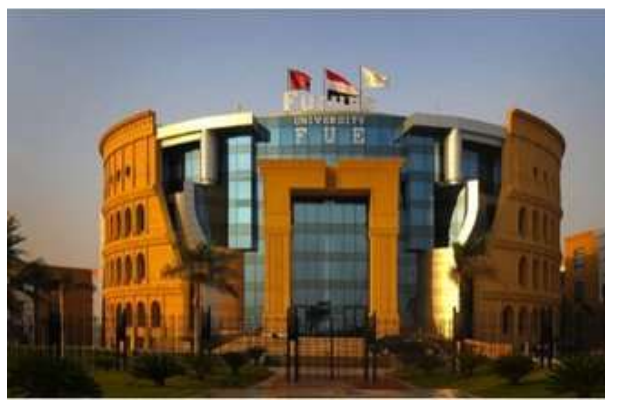

\section{6-Classification of architectural identity that affects the national identity:}

Maintaining our national architectural style for a long interval of time with its features is essential, as it affects our life style. Elevations is the transition and isolation between indoor and outdoor, Religious factors play a basic role in our design that affects the social political factors as well, such 
as Islamic architecture, with its little openings. Where most of our buildings are fenced inspired from Islamic architecture fences. It gives the sense of compacted unit and isolation, reflected on its facades, walkways, and urban context. Architectural style should have an added aesthetical visual impact to have its specific value.
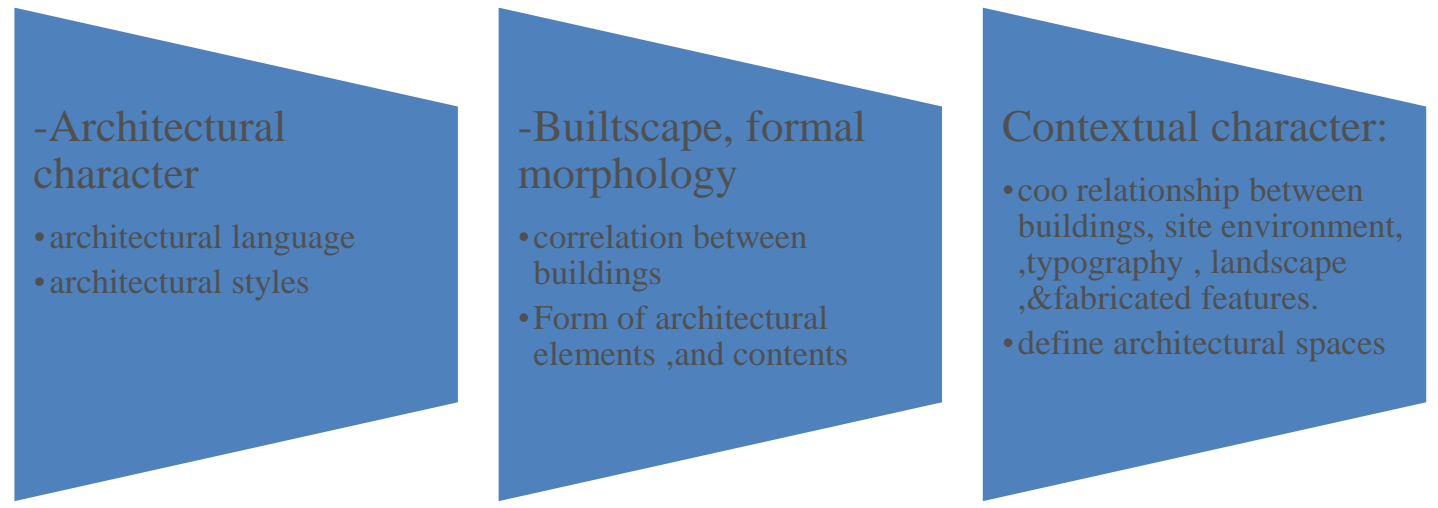

Figure 15 shows the factors affecting national architectural identity

\section{6-1-Relation between identity, style and character:}

Character or identity are all one in meaning, where it identifies social culture that is related to place and timing, and its existed art inventive. Webster identifies it by its specific unique individuality, social character style and Ego identity are variable upon circumstances. As Culture is identified by gathers certain level of society, with common standard, to assure the human attitude saving their beauty, designed by specific pioneers. To upgrade the architectural style in having a successful interaction of human with the environment to cope with its spiritual issues. Transfer of symbolic architecture culture begins by its requirements matching with its inherited culture.

\section{6-2-Character and style:}

Architectural style is identified all over time by its specific ornaments and details as in Islamic architecture, that is constant, and inherited but couldn't been applied on any building.

\section{6-3-Physical feature of Architecture:}

It is a reflection of the continuity of its culture saved by mind, related to a certain time. where there must be hierarchy in development, extracted from the land, living standards, traditions, and morals. The success of place in having identity is in being

saved by its specific feature as a visual photo. So, the form Differs in its elements and external factors affecting its concepts and its negative factors affecting human activity, that doesn't have any aesthetical visual value .as when we

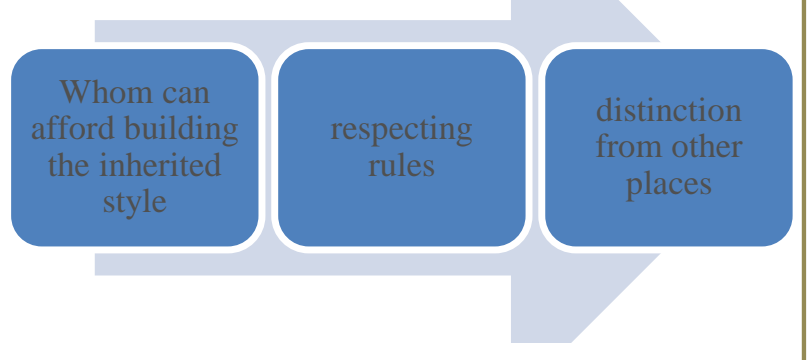

Figure (16)shows the factors affecting architectural style

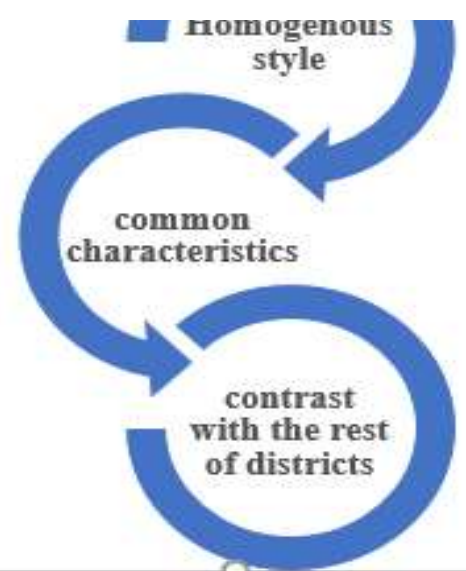


get used on ugliness, we couldn't distinguish between beauty and awful image.

\section{7-Classification of Special activities upon nature of architectural spaces:}

It differs upon time of the individuality activity and its requirements. Ja $n$ Gehl defined the life between buildings into three different kinds of activities

7-1-define the usual important activities (residence, work, define society behavior.The Optional activities shown on external factors for extension for human motivation \& visualization as External spaces gardens

- define time of Activities inside building

- time mapping for the Time interval activity

- Seasonal annual requirements

Figure (17) shows the spiritual impact on solving the architectural style barriers

\section{7-2-Motion of people:}

Common features in the architectural elevations mainly out of having common human activates.

Distinguish the different types of activities in its impact (positive or negative activity). Elevations in architecture have different definitions, articulation, traditions, concept and form. Each building has its different function with is visual arts, and social culture.

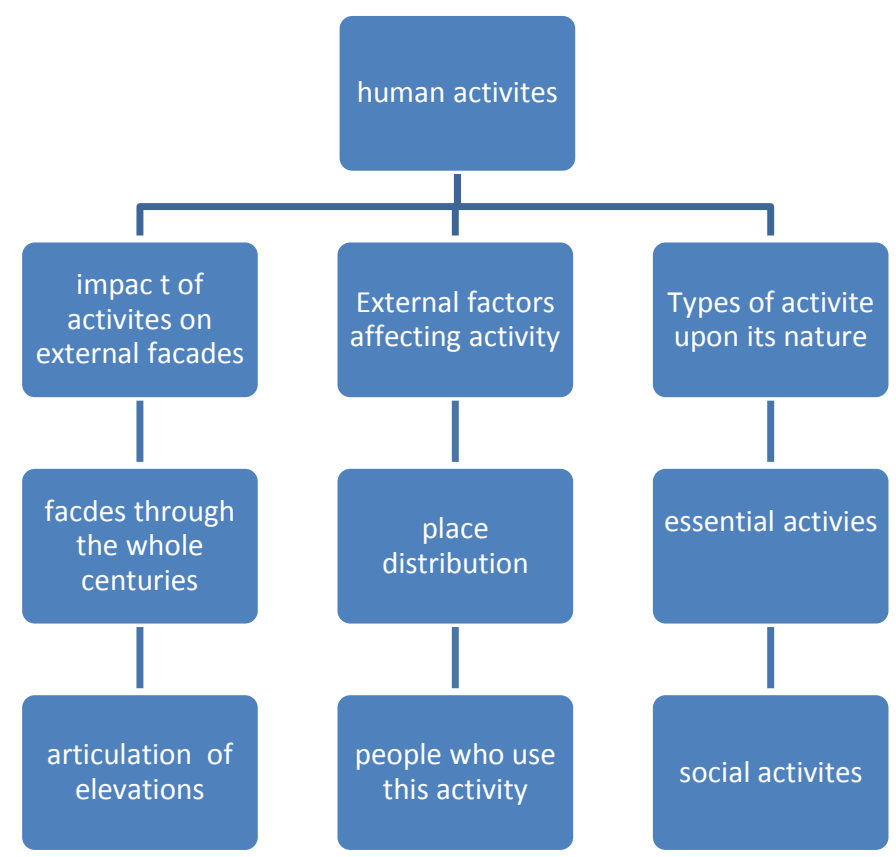

Figure (18) shows the impact of human activities on elevations

\section{8-Methodology applied for Classifying of elevations:}

Table (3) shows the variable indicators affecting architectural identity

\begin{tabular}{|l|l|l|l|l|}
\hline Indicator & $\begin{array}{l}\text { Livable } \\
\text { referring to the }\end{array}$ & $\begin{array}{l}\text { Sustainable } \\
\text { elevation- }\end{array}$ & Social & $\begin{array}{l}\text { Elevation } \\
\text { design }\end{array}$ \\
\hline
\end{tabular}




\begin{tabular}{|c|c|c|c|c|}
\hline & people & urban context & context & $\begin{array}{l}\text { related to its } \\
\text { function }\end{array}$ \\
\hline $\begin{array}{l}\text { The Building } \\
\text { character of } \\
\text { its element } \\
\text { with its } \\
\text { function. }\end{array}$ & $\begin{array}{l}\text {-Elevations } \\
\text { language: }\end{array}$ & $\begin{array}{l}\text { Visual } \\
\text { pollution on } \\
\text { streets squares, } \\
\text { access to } \\
\text { productivity, }\end{array}$ & $\begin{array}{l}\text { historical } \\
\text { background } \\
\text { productivity, } \\
\text { employment }\end{array}$ & $\begin{array}{l}\text { High leveling } \\
\text { Horizontal or } \\
\text { vertical } \\
\text { extensions }\end{array}$ \\
\hline $\begin{array}{l}\text { the } \\
\text { geographical } \\
\text { orientation. }\end{array}$ & $\begin{array}{l}\text { Edges at the } \\
\text { main street } \\
\text { Typography } \\
\text { (humps and } \\
\text { contour) }\end{array}$ & $\begin{array}{l}\text { Noise } \\
\text { pollution, } \\
\text { Monitoring, } \\
\text { resilience }\end{array}$ & $\begin{array}{l}\text { provision of } \\
\text { recreational } \\
\text { facilities, } \\
\text { accessibility }\end{array}$ & $\begin{array}{l}\text { Leadership, } \\
\text { Monitoring, } \\
\text { productivity }\end{array}$ \\
\hline $\begin{array}{l}\text { Unity of shape } \\
\text { and contrast }\end{array}$ & $\begin{array}{l}\text { Main masses } \\
\text { Repetition of } \\
\text { details }\end{array}$ & $\begin{array}{l}\text { polluted visual } \\
\text { aspects } \\
\text { monitoring }\end{array}$ & $\begin{array}{l}\text { Comfort } \\
\text {, participation }\end{array}$ & participation \\
\hline Elevation size & Skyline & health, safety & $\begin{array}{l}\text { Environmental, } \\
\text { street frontage } \\
\text { walkability }\end{array}$ & $\begin{array}{l}\text { Main façade } \\
\text { External } \\
\text { additions to the } \\
\text { existing building }\end{array}$ \\
\hline Building value & $\begin{array}{l}\text { Building } \\
\text { entrances } \\
\text { (elevations, } \\
\text { within lots of } \\
\text { details) }\end{array}$ & $\begin{array}{l}\text { community } \\
\text { engagement, } \\
\text { well being }\end{array}$ & $\begin{array}{l}\text { historical } \\
\text { background } \\
\text {, provision of } \\
\text { recreational } \\
\text { facilities }\end{array}$ & $\begin{array}{l}\text { Conversion of } \\
\text { buildings that } \\
\text { affects its } \\
\text { existing facades }\end{array}$ \\
\hline $\begin{array}{l}\text { Elevation } \\
\text { Texture and } \\
\text { its color }\end{array}$ & $\begin{array}{l}\text { Responsibility, } \\
\text { Diversity, } \\
\text { connectivity }\end{array}$ & $\begin{array}{l}\text { Cooperation, } \\
\text { affordability, } \\
\text { inclusion }\end{array}$ & $\begin{array}{l}\text { Comfort, } \\
\text { planning, } \\
\text { environmental } \\
\text { responsibility }\end{array}$ & $\begin{array}{l}\text { Management, } \\
\text { access to } \\
\text { employment, } \\
\text { diversity }\end{array}$ \\
\hline
\end{tabular}

8-1-The main elements reflected on design, and building elevations: 


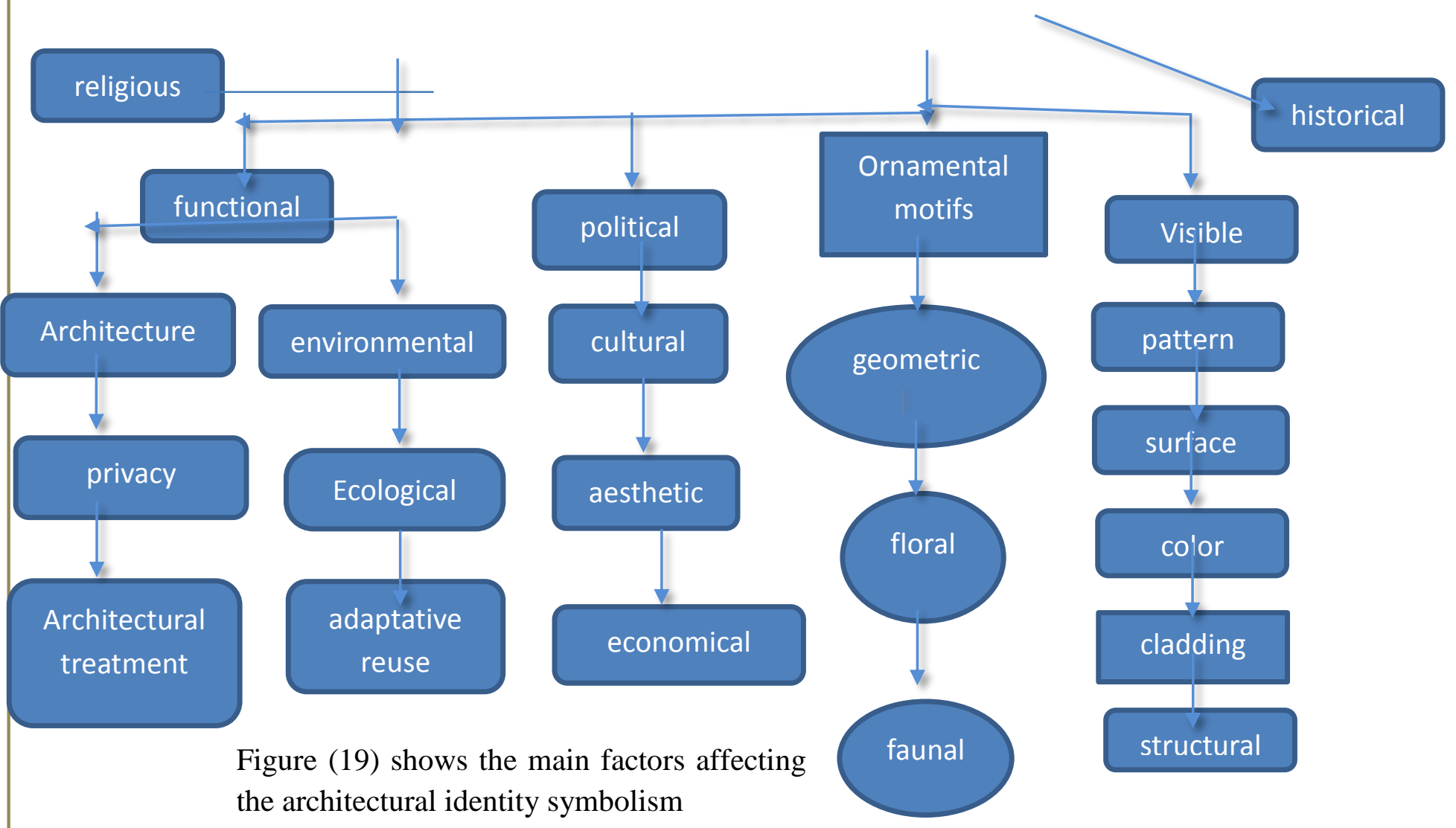

\section{8-2-National symbols express the specific national identity:}

Architectural structure is an essential indicator for showing the architectural identity. So, the country has to cope with updated modern developments in its architectural historical buildings.

The building can relatively give historical region's own identity by its reflection on urban context, showing the progress that taken place in the region through its and spatial planning through different interval of time. But the obstacle facing Egypt is the Complexity of its region, and the difficulty in distinguishing its architectural identity out of diversity in using different traditional components in the same building. However, Egyptian architectural identity could be specifically elaborating on landmarks as a historical building in this region and distinguishing it as a concept of individual regionalism. Critical regionalism can be defined as region's architectural history expression, as it considers specific elements of certain buildings as an effective reflection impact (Frampton, 2004).

The region culture and its elements give the architectural expression especially in its architectural form, as well as sustainability, gives identity to the inherited buildings. It is a suitable atmosphere once the architect's design is a traditional design. The critical regionalism approach is to merge the specific individualities of the place influence with the worldwide civilization. (Canizaro, 2007, p. $395)$. 


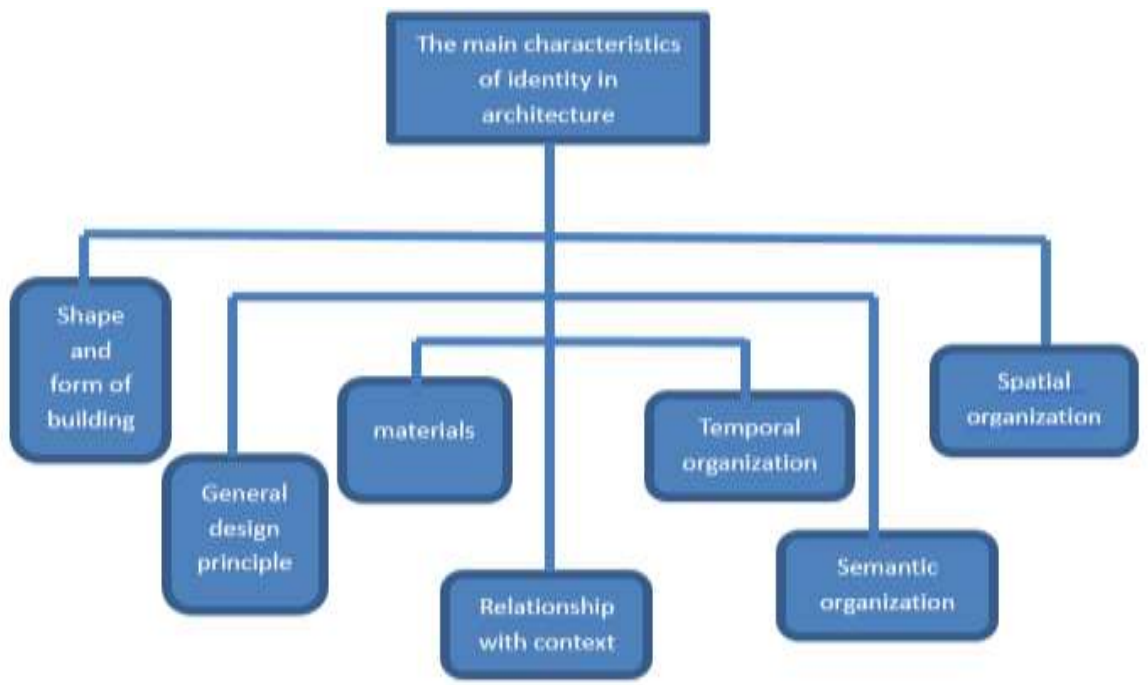

Figure (20) shows the main characteristics of architectural identity

\section{Conclusion}

The research mainly depends on finding a specific Egyptian architectural character upon its urban context, and orientation.

- First phase: Documenting several reflected changes upon the user's interaction

- Second phase: applying visual aspects and site analysis for the existed historical building, within identifying its form, walkways, texture, colors, shape, ways, mass)

- Third phase: apply analytic survey to identify the capabilities needed to create regional culture. Within few categories, there are certain features

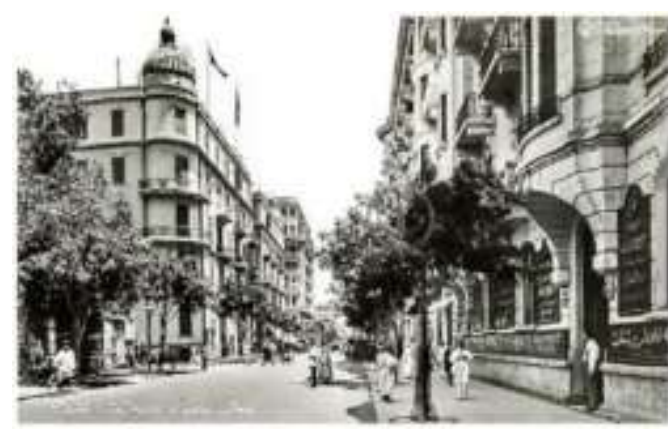

Figure (21) shows the Selman basha street identity as a visual aspect for regionalism, such as regional climate conditions, consciously bounded architecture, reinterpreted vernacular elements, marginal practice, and architecture as tectonic fact. (Frampton, 2004, p. 327).

- Fourth phase: Identify architecture specific features, that can be used to explain how to apply the architectural historical landmark responds to distant in each region as identity. Examples Egyptian Vernacular style Hassan Fathy domes that was built as a sustainable poor architecture built out of clay, and buy now it is used as a style for luxurious resorts.

- Fifth phase: Studying the influence of the building's architecture identity on its region as an ideological, folkloric and anthropological regionalism, that reveals the architecture at that time (Pavlides, 2007,
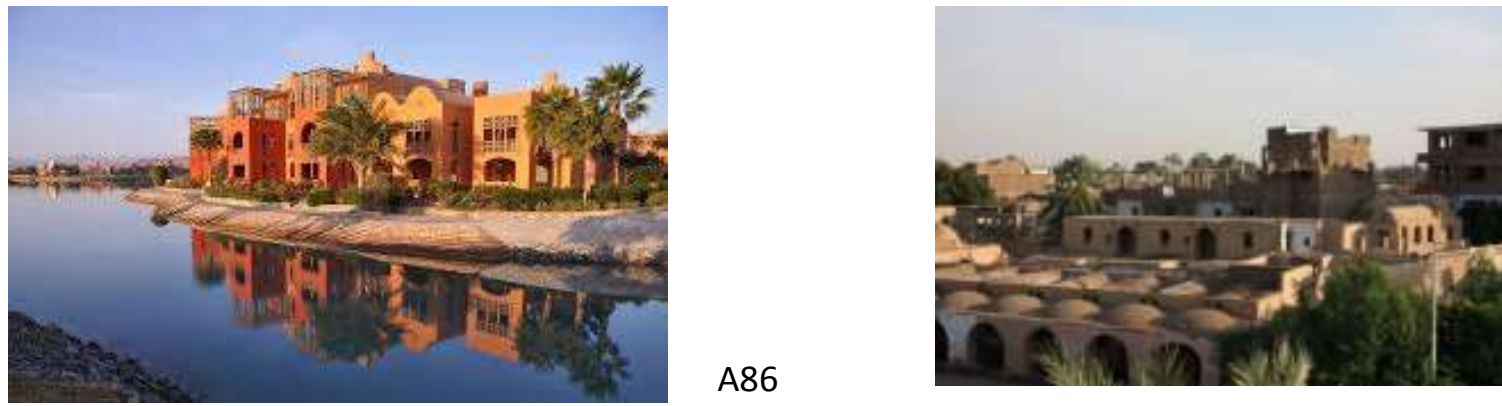
Figure (22) shows the goanna hotel resort influenced by Hassan Fathy style

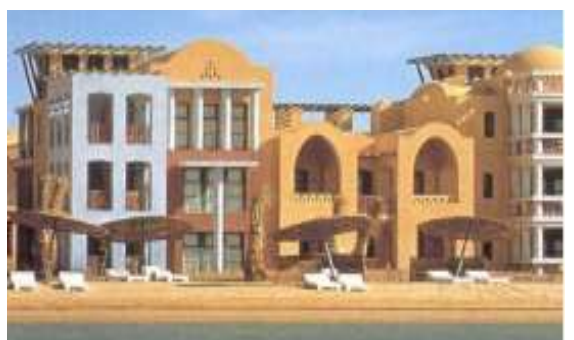

Figure (24) shows Sheraton Miramar resort influenced by Hassan Fathy
Figure (23) shows new gourna village by Hassan Fathy style

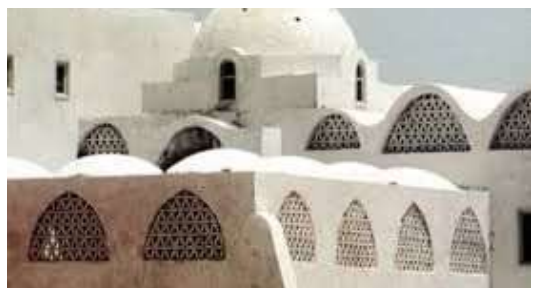

Figure (25) shows Hassan Fathy rest house verna

- The research attempts to formulate unity in its analytical methodology in resolving the Egyptian architectural identity problems. This approach illustrates the relations between building character and inner function relationship affecting its urban context, so as to reach to the common basic ground to be a guideline in the design perception.

- Sixth phase: Finding The shortage facing specific Egyptian identity, and how to avoid the shortage in development affecting it.

- Seventh phase: The effective verification for architectural style is by studying the existed building circumstances as a visual attempt, applying the authorized legalization, to conserve it from demolition. So, differentiate between variable and constant factors affecting the architectural identity in external facades in its form, shape of openings, ornaments, colors and texture.

- The architect plays a great role in respecting regional climate conditions in his design to cope with the human environment (Turner, 2003). Finding the effective co relationship connection between national architecture and its regionalism. (Harwell, 2007, p. 57). where there are limited rules should be followed to choose the building materials, where it has to be native to the region itself, using traditional materials, resembling its identity.

- Eighth phase: Maintain and preserve the existed traditional construction methods and designs, as it is about to vanish, because of modernization. Applying equity, rather than isolation between people to increase loyalty, by increasing the relationship interpretation between building's design and region 's people "A national expression, on the other hand, is, at its highest, the expression of consolidation. This is because a nation is a people consolidated. The purpose of a national architecture is to further unite people as citizens. Since the nation is essentially a symbol, a national architecture must provide an image of the qualities the nation symbolizes" (Harwell, 2007, p. 61)

- Identifying architectural identity helps in the retain and revival of our national Egyptian heritage to its original shape. As most of inherited buildings can reconstructed a after destruction to preserve its original identity as a city landmark. (i.e., whereas in post-war of 
what is worth preserving to identify its national originality, and the country action plan in preserving it.

- Nineth phase: Applying a plan to express new identities, merging with our heritage, taking into consideration that a landmark architecture turns to be a place metaphor, to its urban context. (Delanty et al., 2001, p. 464).

\section{References:}

- Bonta, J. P. (1981). Architecture and its interpretation: A study of expressive systems in architecture.Canizaro, V. B. (2007). Architectural regionalism: Collected writings on place, identity, modernity, and tradition. Princeton Architectural Press.Jashari-Kajtazi, T., \& Jakupi, A. (2017). Interpretation of architectural identity through landmark architecture: The case of Prishtina, Kosovo from the 1970s to the 1980s. Frontiers of Architectural Research, 6(4), 480-486.Balik, D., \& Allmer, A. (2016). A critical review of ornament in contemporary architectural theory and practice. ITUJ Faculty Arch, 13(1), 157-169.

- Bothireddy, H. (2007). Syntactic and semantic role of ornament in architecture (Doctoral dissertation, University of Cincinnati).

- Canizaro, V. B. (2007). Architectural regionalism: Collected writings on place, identity, modernity, and tradition. Princeton Architectural Press.

- Catalani, A., Nour, Z., Versaci, A., Hawkes, D., Bougdah, H., Sotoca, A., ... \& Trapani, F. (Eds.). (2018). Cities' Identity Through Architecture and Arts: Proceedings of the International Conference on Cities' Identity through Architecture and Arts (CITAA 2017), May 11-13, 2017, Cairo, Egypt. Routledge.

- Critical positions in architectural regionalism/ Regionalism and Nationalism in Architecture. In: Canizaro, B.Vincent (Ed.), Architectural Regionalism, Collected Writings on Place, Identity, Modernity, and Tradition eds. Princeton Architectural Press, New York, pp. 57-61. Jakupi, A., 2013.

- Delanty, G., \& Jones, P. R. (2002). European identity and architecture. European Journal of Social Theory, 5(4), 453-466.

- Elrayies, G. M. (2018). Architectural ornaments in the twenty-first century: An analytical study'. Cities' Identity Through Architecture and Arts-Catalani et al.(Eds), Taylor \& Francis Group, London.

- Jashari-Kajtazi, T., \& Jakupi, A. (2017). Interpretation of architectural identity through landmark architecture: The case of Prishtina, Kosovo from the 1970s to the 1980s. Frontiers of Architectural Research, 6(4), 480-486.

- Majewski, M. (2012, December). Geometric ornament in art and architecture of Western cultures. In 17th Asian Technology Conference in Mathematics (pp. 14-29).

- McNicholas, M. T. (2006). The relevance and transcendence of ornament: A new public high school for the South Side of Chicago (Doctoral dissertation, University of Notre Dame). Ornamental art and architectural decoration. Procedia-Social and Behavioral Sciences, 51, 567-572. Moussavi, F. \& Kubo, M. (2006). The function of ornament. Actar. Opincariu, D. (2011).

- Opincariu, D. (2011). Structure and Building Facades, the new concept of ornament. Acta Technica Napocensis, 54(2), 193-203. 
- Pallasmaa, J. (1988). TRADITION AND MODERNITY, THE FEASIBILITY OF REGIONAL ARCHITECTURE IN POST-MODERN SOCIETY. Architectural review, 183(1095), 26-34.

- Picon, A. (2014). Ornament: The politics of architecture and subjectivity. John Wiley \& Sons.

- Sandle, D. (2000). Public Art and City Identity. Political and cultural issues in the development of public art in the UK city of Leeds. on the w@ terfront. Public Art. Urban Design. Civic Participation. Urban Regeneration, (2), 91-103. 